\title{
Development Induced Displacement and State Policy Implementation: A Case of Welkayt Sugar Factory in Tigray Region, Ethiopia
}

\author{
Bereket Godifay Kahsay \\ Department of Anthropology, Institute of Paleoenvironment and Heritage Conservation, Mekelle University, Mekelle, Ethiopia \\ Email address: \\ bereketgodifay@gmial.com \\ To cite this article: \\ Bereket Godifay Kahsay. Development Induced Displacement and State Policy Implementation: A Case of Welkayt Sugar Factory in Tigray \\ Region, Ethiopia. Journal of Investment and Management. Vol. 10, No. 2, 2021, pp. 22-29. doi: 10.11648/j.jim.20211002.11
}

Received: April 5, 2021; Accepted: April 27, 2021; Published: May 14, 2021

\begin{abstract}
Ethiopia is realizing several development projects out of which sugar development projects the major one. It is expected that a large-scale project would result in the displacement of people. When the displacement of people occurred due to development project, it is likely that government provide compensations and have clear procedures for the resettlement process. With the aim of evaluating the existence and implementation of resettlement policy and examining the relocation process in the case of Welkayt sugar factory development project, this research was conducted in Tigray region of Ethiopia. Precisely, the study aimed at evaluating the implantation of Ethiopia's proclamation on landholding expropriated for public purposes and examining the resettlement process, and identifying major challenges encountered during the resettlement process. To meet these objectives, a household survey, focused group discussions, interviews, and observation was employed to gather the primary data. The research design and approach were descriptive and qualitative respectively. The study shows that Ethiopia has a proclamation on expropriation of landholdings for public purposes and payment of compensation since 2005. The Tigray regional state has likewise established a resettlement action plan for this specific development project. The Woreda administration was also active in the process of resettlement. This development project is evaluated to be positive in the fulfilment of basic service in the resettlement area. The government proclamation on the designation of property valuation committee, provision of replacement land, determination and payment of compensation, and establishment of complaints and appeals concerning the compensation were realized in the study case. Though evaluated to not have a similar purpose, replacement land was given for taken agricultural land, grazing land, and burial grounds. Compensation for the house removal related costs has been provided, while a promise was given by the government for the unreplaced agricultural land. Several challenges by the government, the project affected people, and the sugar development corporation were encountered in the process of resettlement. Similar projects of the future are recommended to be informative and transparent of the relocation process to the public.
\end{abstract}

Keywords: Development-Induced, Displacement, Policy, Compensation, Ethiopia

\section{Introduction}

The term "development" has numerous meanings to different people and can be described in diverse settings [1]. Development means "the conditions for realization of the human personality [1]. Its evaluation must therefore take into account three linked criteria: where there has been a reduction in (1) poverty, (2) unemployment, (3) inequality" [1]. When discussing society or a socioeconomic system, development typically refers to the improvement, either in the overall situation of the structure, or in some of its essential elements [2]. Development does not denote a specific viewpoint on social, political and economic advancement, it rather is a mixed term for several approaches accepted for socioeconomic and environmental transformation from current states to anticipated ones [1].

In the 1950 s and $1960 \mathrm{~s}$, the leading view in development came from the side of modernization theory which sensed development as transforming undeveloped societies into modern, complex and westernized ones which resulted in 
large-scale, capital-intensive development projects that accelerated the leap towards a brighter and better future [19]. However, in recent decades a 'new development paradigm' has been expressed, one that considers poverty reduction, environmental protection, social justice, and human rights as major parts of pursuing development [19]. In this paradigm, development is understood as having both benefits and costs. Among development's greatest costs, the internal displacement of millions of vulnerable people is the fundamental one [21]. Development is the main driver of dislocation and a challenge for humanitarian actors [16].

Displacement is the uprooting of people from their place of habitual residence [4]. Displacement is described as "dislocation of people from their native place and region [16]. It often exacerbates rather than mitigates economic insecurity, helplessness and alienation". The literature review outlines the major causes of internal displacement into three typologies, i.e. development-induced displacement, conflictinduced displacement and disaster-induced displacement [14]. The development-induced displacement has come to be acknowledged as among the most significant negative consequences of development projects [18].

The study of development induced displacement and involuntary resettlement has a relatively extended and readily noticeable history in the field of development and forced relocation studies [17]. However, it gained recognition as a key issue for analysis and policy during the 1990s [11]. Reviewing development-induced displacement, in sociology and anthropology, development-induced displacement appeared both as a major concern and as a challenge in the 1990s [7].

One of the progressively heard voices is that of people displaced and relocated by development projects because development has resulted in the separation of local life from the sense of place which is experienced by millions of people around the world [20]. Dislocation of people in the context of development interference has been recognized as "the most important forced migration problem worldwide" of our time [8].

The World Bank Environment Department (WBED) estimates that roughly 10 million people are displaced each year, globally, due to dam building, urban development, transportation and infrastructure programs [15]. In 1994, a study of World Bank-assisted development projects from 1986-1993 that involved population dislocation concluded that, in the early 1990s, the construction of 300 high dams (above 15 meters) each year had displaced four million people, while urban and transportation structure projects accounted for six million more displaced each year [15]. Displacement resulted from development projects like dams, roads, state-owned plantations, mining, pipelines, and urban reconstruction is estimated to be between 100 and 200 million people since 1980 that happened internationally [10].

The percentage of population and territory affected by projects in Africa is considerably higher than in other continents [5]. Resettlement caused by government-funded development programs has produced and continues to produce, a different set of challenges on the African continent [5]. For example, the construction of main dams in Africa, specifically during the $1960 \mathrm{~s}$ and $1970 \mathrm{~s}$ has entailed population displacements of large scale [7]. He added that many Africans with many continuing development programs that result in large scale displacement do not have a national policy regulating displacement caused by public sector investment.

Policy-wise, Operational Policy (OP) 4.12 remains the most widely used guideline for any project involving involuntary resettlement [15]. This policy comprises direct economic and social impacts that both result from Bankassisted investment projects and applies to all components of the project that result in involuntary resettlement, regardless of the source of financing [24].

To not have a national policy to deal with development induced displacement, therefore, aggravates the living condition of the project affected people after the resettlement. Even with the existence of policies to manage involuntary displacement, several challenges happen when realizing resettlement. The fundamental challenges encountered during executing resettlement include inadequate funds, poor record management of the displaced people, alleged inequality in the resettlement process, failure to involve and consult with stakeholders, lack of social amenities and basic infrastructure, and hostility between the displaced people and the host community [23].

In Ethiopia, displacement is prominent in development projects aiming at many development structures such as the extension of irrigation and hydropower construction, the delivery of improved housing in urban centres, and the establishment of national parks [8].

One of the major development projects in Ethiopia is the establishment of sugar factories. The Ethiopian Sugar Corporation, as agro-processing commerce, alters hundreds of thousands of hectares (ha) of land in the lowlands into many purposes of the sugar business [22]. The construction of sugar factories as development projects requires land for the erection of the factory, a catchment area for the creation of small dams, and a very massive area for the cultivation of sugarcane. In possessing the land to be used for the mentioned purposes there is a high possibility of displacement of people.

The Welkayt sugar factory in Tigray is one of the big development projects of the Ethiopian government. The project's dam, factory, and agricultural field to cultivate sugarcane are situated in Welkayt Woreda of Western Tigray. Close to $80 \%$ of the farmers in the study site raise crops and livestock, while $10.96 \%$ only grew crops and $9.4 \%$ only raised livestock [3]. The factory has resulted in a displacement of more than two thousand six hundred households in 2013, although the total number of displaced households has reached 6,767 by 2019 . Two district administrations with many small villages were affected by the displacement, and more than 50,000 hectares of land was taken from the farmers [6]. Hence, the research aimed at studying the existence of state policy to manage such 
displacement and evaluate the implementation of the policy. Specifically, the study intended to evaluate the existence and implementation of Ethiopia's proclamation on landholding expropriated for public purposes and to identify the major challenges encountered in the process of realizing the resettlement.

\section{Methodology}

\subsection{Research Design and Research Approach}

The research design for this study was descriptive, and qualitative research was the research approach.

\subsection{Data Collection Tools}

Both primary and secondary sources of data were used. Secondary sources analysis was utilized to strengthen the findings from the primary sources. The period during which the primary data collection was held was February and March 2020. The following primary data collection methods were utilized to reply to the research questions and produce a report based on the specified study objectives.

Survey- using structured questionnaires, a qualitative survey was conducted for 347 households. Utilizing this data collection method, information on timelines and magnitude of the compensation, and the overall process of the relocation was collected.

Focus Group Discussion (FGD)- focus group discussions were held with two homogenous groups from the displaced people, segregated by sex. There were $8-12$ participants in each group. The focus group discussion lasted at a maximum of one hour and thirty minutes. Themes on the implementation of government proclamation on payment of compensation and challenges encountered during the implementation of the relocation were discussed.

Interviews- key informant interviews with six people from stakeholders and an in-depth interview with 10 displaced people were conducted. A community leader, a compensation committee member, three local government office heads, and an expert from the sugar factory were questioned. The number of key informants was determined by data saturation. Additionally, an in-depth interview with 10 (2 F) displaced people, selected purposefully from the survey participants, have been conducted. In all interviews, subjects on payment of compensation, procedures are undertaken to relocate the displaced people and challenges faced were conferred.

Observation: the researcher has used a systematic nonparticipant observation to physically see the resettlement camp situation, the social service centres constructed in the resettlement area for the project affected people, and the land take for the project.

\subsection{Sampling Design}

The primary resettlement was made for 2,624 households in 2013, the number of displaced has reached 6,767 households by 2019 though. Therefore, 2,624 households were the population size to take the sample to assess the impact of the resettlement on the relocated households. Taro Yamane's sample size determination formula was adopted, and 347 households were selected for the survey. To identify the survey participants, systematic random sampling was used. A sample frame of the master list of the displaced households was used to identify the respondents.

\section{Result and Discussions}

\subsection{Description of the Study Area}

In 1,300 Km north of Addis Ababa, Welkayt Sugar Factory is located at Welkayt Woreda administration, Western Tigray. The Woreda is among the most populous in the Zone which has a population of 138,926 according to data from the Central Statistics Agency [3]. Welkayt is known for its fertile sedimentary soil. The means of substance for the rural people is agro-pastoralism.

\subsection{Resettlement Process and Implementation of State Proclamations on Compensations for Property Taken for Public Purpose}

\subsubsection{Existence and Implementation of Resentment Policy and Resettlement Action Plan}

The Government of Ethiopia (GoE) has regulations to smoothen the resettlement program of the developmentinduced displacement, since 2005. Proclamation No 455/2005 'Expropriation of Landholdings for Public Purposes and Payment of Compensation' establishes the legal procedure and outline for expropriation and compensation. According to this proclamation, the implementing agencies of the displacement have a responsibility to prepare detailed information affecting the land needed before the commencement of the works that would help them obtain permission to pay compensation per the proclamation.

The regulation has clearly stated procedures of depriving of landownership namely state power to expropriate landholdings, notifications of expropriation order, responsibilities of implementing agency, and procedures for removal of utility lines. It also ponders the determination of compensation explicitly the basis and amount of compensation, displacement compensation, valuation of property, the establishment of property valuation committee of not more than five experts, and grievances and appeals process concerning the compensations.

Hence, the state has a protocol to deal with developmentinduced displacement and declares that landholders whose holdings have been expropriated must get compensations. Clearly stating the responsibilities of government organs from Federal Ministries to local offices, the proclamation also visibly articulates how the compensation must be determined and the procedure of its implementation. Moreover, this proclamation states that the Council of Ministers and the Regional States may issue regulations necessary for the effective implementation of this specific regulation.

The "Payment of Compensation for Property Situated on 
Landholdings Expropriated for Public Purposes- Council of Ministers Regulations No. 135/2007" is another regulation set by the government of Ethiopia. In its four major parts, this proclamation describes the assessment of compensation, provision of replacement land and payment of displacement compensation, and other miscellaneous provisions.

This regulation states that assessment of compensations must be made for buildings, fences, crops, perennial crops, cultivated trees, protected grass, permanent improvement of rural land, relocated property, mining licenses, and burial grounds. There are specific formulas for each of the abovementioned assets to calculating the number of compensations payable under the proclamation. The directive also has a section in which it states a replacement land must be given for urban land, rural land, and protected grass or/and grazing land.

For the study case, according to the key informant from Tigray Bureau of Agriculture, Tigray Regional State has established a resettlement action plan to effectively manage the resettlement process. The action plan specified the process of the relocation, and it incorporates a livelihoods strategy to benefit the project affected people from the project. The plan also states that additional human resource would be hired by the Regional State to follow and monitor the effective implementation of the government proclamation and the resettlement action plan, according to a keyInformant from the regional bureau. The key informant added that he is one of the experts hired to monitor the successful operation of the resettlement process. The researcher, however, could not access the action plan.

Considering the existence and implementation of resettlement policy and the prepared action plan as a fundamental requirement for successful application of resettlement, the study case is appraised to have both policy and directives to execution the resettlement.

\subsubsection{Community Consultation and Establishment of the Property Valuation Committee}

The resettlement process was required to have a community consultation at the initial stages aimed at getting the consensus of the community to move to the resettlement camp. The decision-making power of migrants, their willingness to consent to their habitual dwelling, the existence of push/pull influences, and the age make-up of transferred people determine the nature of the resettlement be voluntary or involuntary [12].

In the study case, continuous community consultations were made by the local government that briefed the construction of the Sugar Factory and irrigation dam in the area. According to the key informants, briefing the relevance of the project, the requirement of extended land for the project and that the land would be taken from the community was discoursed. The survey also shows that $93 \%$ of the respondents agreed that the community was consulted about the project and the necessity of the community relocation.

However, the community members had a strong position that they did not want to leave their area, regardless of the relevance of the project to the local people and national economy. From the survey respondents, $92 \%$ of them said they did not agree on the relocation and that all decisions were not based on their consensus, they were imposed on them.

Resulted from the strong position of the people, the experts from the government had to come up with dishonest promises that life would be better in the relocation area as the government and Sugar Corporation would take care of everyone, the FDG participants revealed. They were informed that nothing would happen for them, the compensation would be in tens of thousands, and that, generally, the new life would be much better than their life in the rural and pre-urban villages. However, the community continued with its position. The government, then, started to hurry the process that decisions were made in a short period and started the relocation process. That is why more than $90 \%$ of the survey respondents thought that the relocation has occurred involuntarily. After the compensations were calculated and provided, the people left their area willingly that no government forces were deployed to move the people.

Although $36 \%$ of the survey participants said that they did not know a committee that was established to value their destructed assets, essentially, there was a committee established to value the assets of the displaced people. As stated in the government proclamation the committee members were designated by the Woreda Administration and the committee comprised five members.

The working procedure of the committee was stated in the directive established by Tigray Regional State. The Woreda administrator manages everything from the managerial side. The committee designated by Woreda administration consists of five members i.e. one expert from Woreda Office of Construction, one Expert from Woreda office of Agriculture, one expert from the Office of Land Administration, and two from the local people. Thus, the implementation of the government proclamation to formulate a property valuation committee, in the study case, was assessed to be effective.

\subsubsection{Fulfillment of Basic Facilities in the Resettlement Area}

When a resettlement camp is established, the fulfilment of basic services in the new resettlement area is the main duty that the government must do to ensure the protection of the project affect people. Basic facilities such as water, environmental and personal hygiene facilities, education, health, and other infrastructures like power and road access must be fulfilled for the displaced people.

In the study case, before the displacement, the project affected people had seven elementary schools, three of them were complete elementary schools (grade 1-8), while there remaining were first cycle schools (grade 1-4). There was one primary clinic that served all the displaced villages, and that both Kalema and Tsebri Tabia administrations had one veterinary clinic each. In the rural villages, there were many hand-pump water points, seven only in Tabia Tsebri. As discussed in the FGDs, resulted from remoteness, the service 
centres were not easily accessible for some of the villages.

In the relocation area, the local administration has built many basic service delivery centres using the money provided by Sugar Corporation. These include one high school, three complete elementary schools (grade 1 to 8), a primary clinic, a kebele administration office, a farmers training school, and four water boreholes with 24 water distribution centres which help the relocated people access basic services. Other facilities like electric power, road, and market areas are also available. The researcher has physically observed the mentioned basic service centres, and other basic services such as power and road facilities are also good in the town. Hence, this development project is evaluated to be positive in the fulfilment of basic service centres in the relocation area for the resettled people.

\subsubsection{Provision of Replacement Land}

The government proclamation states that when land used for agriculture or protected grass or grazing land is taken for a public purpose, the holder of such land shall, as much as possible, be provided with a plot of land capable of serving a similar purpose. In the study case, the displaced people had residential and agricultural lands, protected grass, and grazing land.

After the relocation, $99 \%$ of the resettled people have residential land in the area where they have been transferred to. Agricultural land, however, happened to be challenging that $86 \%$ of the surveyed households referred to irregularity in the provision of replacement land. The key informant from local government officials stated that only $50 \%$ of the agricultural land taken was replaced with another plot of land as the local government could not find enough space to provide the required replacement area. The local government then promised to provide compensation for the remaining unreplaced land. However, the pledged compensation was not delivered until this study was conducted which resulted in a public demonstration of the displaced community in May 2020 .

Although evaluated not to serve a similar purpose, plots of land for grazing land have been provided for the displaced people in the new settlement area. Replacement of burial grounds, basic service centres, and religious institutions was also provided for the project affected people.

\subsubsection{Determination and Payment of Compensation}

As articulated in the government proclamation, the designated compensation valuation committee was responsible for determining the amount of the compensations. The committee has valued compensation for buildings, fences, trees, relocated property, and land used for growing crops. The compensation for relocated property included the estimated cost of labour, material and transport for removing, transferring, and installing the property. The determination of the compensation was made considering the up-to-date market values. And, the formulas declared by the government were used to compute the compensation amounts.

After the compensations were calculated and communicated to the people, $84 \%$ of the survey respondents have agreed that the compensations provided for the removal and erection of the residency house was on time. However, $95 \%$ of them said that they were not informed how all the compensation packages were calculated. The communication to the people about the displacement and amount of compensation was not on a written basis.

As discussed above, the promised compensation sworn for the agricultural land has taken six years that it was not provided for many people until this research was conducted. Yet, a general evaluation was made for the provided compensation. From the survey participants, $44 \%$ of them have rated their general satisfaction on the provided compensations as 'very poor, while $50 \%$ of them rated 'unsatisfactory', $6 \%$ of them rated 'satisfactory' and none of them rated 'very good.

The compensation valuation committee did not determine compensation for protected grass, crops and perennial crops, burial grounds, and compensation for permanent improvement of rural land. Hence, no compensation was provided for crops and perennial crops as the relocation has taken place after the harvesting season. Besides, no compensation was given for protected grass and burial grounds since replacement land was provided and that no protected grass requires compensation.

Notwithstanding the satisfaction of the project affected people on the provided compensation, considering the time taken to provide the promised compensation, the implementation of the government proclamations on determination and payment of compensation is assessed to be cheerful.

\subsubsection{Complaints and Appeals in Relation to the Compensation}

To deal with any complaints concerning the compensations, a committee was established at the Woreda level said the key informant from the local administration. This committee consists of four administratively assigned individuals. The finding from the survey also showed that $86 \%$ of the respondents knew the committee which heard grievances related to the compensation at Woreda level.

The government proclamation stated that an administrative organ to hear grievances related to compensations is not yet established that complaints relating to the amount of compensation shall be submitted to the regular court having jurisdiction. The FGDs have confirmed that there was an assigned team to deal with the matter and it was expressed that there was even an appeal system to Woreda level for any issues that remained unresolved at Kebele level. Hence, the option of referring the case to the regular court having jurisdiction has been there.

\subsubsection{Examination of the Responsibilities of Government Organs}

The government proclamation on expropriation of landholding for public purposes and payment of compensation has state responsibilities for different 
government organ. The Ministry of Federal Affairs has been assigned for the implementation of the proclamation with specific duties to follow up and share the proclamation, support technically and capacity building to regional states, and preparation of national valuation formula for determination of compensations and submit to the council of Ministers for approval. The formulas are declared by the Council of Ministers, and Tigray regional state has full knowledge of the proclamation, hence the Ministry of Federal Affairs has managed its duties.

The proclamation has sections in which it gives the power to issue regulation and directives to the Council of Ministers and the Regional States. Both the council of ministers and Tigray regional state have issues regulation necessary for proper implementation of the proclamation, hence have managed their responsibilities.

The Woreda and urban administration offices, as government organs responsible for the implementation of the proclamation, have specified duties to pay or cause the payment of the compensation, maintain data of properties removed from expropriated landholdings. The Woreda administration of the study case has facilitated the payment of the compensation to holders of expropriated land based on the proclamation and has preserved data of belongings removed from the taken landholdings. The researcher has physically observed the filing system of the Woreda administration and has evidenced that the list of the displaced people with their destructed assists has been filed properly.

Even though some fragmentation on the final stages of the provision of the compensation was observed, the government organs have dealt with the duties assigned for them to properly implement the government proclamation.

\subsection{Challenges Encountered During the Resettlement Process}

Throughout the relocation process, several challenges were encountered by the project affect people, local government, the sugar corporation. The project affected people were challenged to deploy their time and energy in the process of the relocation they had to invest more for the reconstruction of their life in the new settlement area. The process of transferring their properties to the relocation place and establishment a completely new lifestyle has not been easy for the displaced people. Normally, the livelihoods and sociocultural setting of the displaced people have been altered, hence have experienced serious encounter in their lifecycle. The local government offices, the Reginal State and Woreda administration have faced one critical challenge. As also discussed in chapter four, when the idea to establish a sugar development project in Tigray, Welkayt, was initiated, the Regional State signed a memorandum of understanding that it would provide a replacement agricultural land. Once the project started, however, the local government could not find enough space to replace the whole agricultural land for all the displaced people. Hence, forced to come up with compensations for the unreplaced land. Therefore, the regional government has been challenged in getting millions of cash to be given in the form of compensation for the land taken from the displaced people. This matter is in the hand of the regional government being discussed, yet.

Another critical challenge encountered by the local administration was to have clear data of the displaced people who had registered land ownership position. As the displacement area was lowland, many people from the highland used to migrate to the area and started using the uncopied land for years without necessarily having land entitlement. This situation, then, happened to be challenging for the Woreda administration to filter the eligible people to give replacement land or/and compensation.

The local government has lost trust in the project affected people as it has taken years to provide the compensation that was promised. Since trust is a virtue difficult to get it back once lost, the local government is, essentially, challenged to deal with other administration works.

The sugar corporation or simply the project was challenged in getting objection from the Waldiba Monastery religious population and local people when constructing the irrigation dam, Zarema Dam, resulted from the perception that the project neglected the holiness of the Monastery which is $18 \mathrm{~km}$ far from the Dam. The community initially perceived, as told by the priests of the monastery, that the dam would serve as a place for the gathering of evil spirits. Moreover, part of the water catchment area belongs to the monastery. When the dam is filled with water, people will cross almost through the monastery which has been perceived by the monastic community and the local community that the holiness of the churches would be compromised.

Another challenge to mention is that project management was challenged in the whole process. Resulted from the unrealistic project activity timeframe, perhaps affected by external factor also, the project progress is far behind its timeframe for accomplishment that the sugar development project was planned to be finished within the first Growth and Transformation Plan of Ethiopia. The expropriated land, for example, was idle for the last five years that the cultivated sugarcane could not be replanted in the vast farming area.

\section{Conclusion}

Ethiopia has a proclamation on expropriation of landholdings for public purposes and payment of compensation and on payment of compensation for property situated on landholdings expropriated for public purposes since 2005 and 2007 respectively. The Tigray regional state has also established a resettlement action plan for this specific development project. This development project is evaluated to be positive in the fulfilment of basic service centres in the resettlement area.

Utilizing the government proclamation, the resettlement process of the study case has followed the necessary steps, especially when designating the property valuation committee and calculating the compensation using the approved formulas. The provision of replacement land and 
the establishment of complaints and appeals concerning the compensation were also based on the proclamation. The timeframe for the distribution of the compensation was evaluated to be on time for the house removal related costs.

However, the provided compensation for the removal of houses was evaluated by the displaced people to be below their estimation, although the valuation of destructed assents involved fence, costs of removal, trees, and costs of transport. Moreover, the compensation for the unreplaced agricultural land was not distributed as promised until this research was conducted.

Examining the responsibilities of government organs, the Ministry of Federal Affairs, the Council of Ministers, the Tigray regional state, and the Woreda administration have been actively managing their respective duties. However, associated with planning problems, irregularities have been discovered about compensation provision. During the project beginning and the whole process of the resettlement, several challenges have been encountered by the sugar corporation, local and regional administrations, and the project affected people. Similar projects of the future are recommended to be informative and transparent of the relocation process to the public.

\section{Declaration}

This study was conducted in February and March 2020. Since conflict has happened in Tigray and several political and administrative changes have occurred towards the end of 2020 , this research has not included the new developments of the study context.

\section{Acknowledgements}

The author is thankful to the Mekelle University-NMBU postgraduate research project fund for fully financing this study.

\section{References}

[1] Abuiyada, Reem. (2008). Traditional Development Theories have failed to Address the Needs of the majority of People at Grassroots Levels with Reference to GAD. International Journal of Business and Social Science Vol. 9, No. 9. Social Sciences Department Dhofar University Salalah, Sultanate of Oman.

[2] Bellù, Lorenzo G. (2011). Development and Development Paradigms: A (Reasoned) Review of Prevailing Visions. ISSUE PAPERS EASYPol Module 102. EASYPol, Resources for policy making.

[3] Central Statistical Authority. (2008). 2007 National Population and Housing Census. Addis Ababa: Central Statistical Authority of Ethiopia. pp. 72-73.

[4] Cernea, Michael. (2005). Concept and Method: Applying the IRR Model in Africa to Resettlement and Poverty. In: Ohata, I. and Yintiso Gebre, (eds). Displacement Risks in Africa: Refugees Resettles and Their Host Population. Tokyo: Kyoto
University Press.

[5] Cernea, Michael. (1997). African involuntary population resettlement in a global context (English). Environment Department working papers; no. 45. Social assessment series, Social Development papers; no. SDP 18. Washington, DC: World Bank.

[6] Dawit Endashaw. (2016). Sugar Project in Welkayit Delays Compensation Plan. Addis Fortune, Vol 16, No 833.

[7] Dwivedi, Ranjit. (2002). Models and Methods in Development-Induced Displacement (Review Article). Published by Blackwell Publishers, Oxford, UK.

[8] Eguavoen, Irit and Tesfai, Weyni. (2011). Rebuilding livelihoods after dam-induced relocation in Koga, Blue Nile basin, Ethiopia. Working Paper Series 83. Center for Development Research, University of Bonn.

[9] Erdiaw-Kwasie, Michae O., Ackuayi, Eric D., Abunyewah, M., and Appiah, Solomon O. (2014). Theoretical and Practical Motives for Participation Obstacles in Resettlement Programs. Review from the Mining Perspective. Journal of Economics and Sustainable Development, Vol. 5, No. 14.

[10] Federal Negarit Gazeta. (2005). FEDERAL NEGARIT GAZETA of the Federal Democratic Republic of Ethiopia: Proclamation. No. 455/2005, Expropriation of Landholdings for Public Purposes and Payment of Compensation Proclamation. Addis Ababa.

[11] Federal Negarit Gazeta. (2007). FEDERAL NEGARIT GAZETA of the Federal Democratic Republic of Ethiopia: "Payment of Compensation for Property Situated on Landholdings Expropriated for Public Purposes Council of Ministers Regulations. No. 135/2007. Addis Ababa.

[12] Gebre Yintiso. (2002). Differential Reestablishment of Voluntary and Involuntary Migrants: The Case of Metekel Settlers in Ethiopia. African Study Monographs (2002), 23(1): 31-46.

[13] Hemer, Susan R. (2015). Emplacement and resistance: Social and political complexities in development induced displacement in Papua New Guinea. The Australian Journal of Anthropology, Australian Anthropological Society.

[14] Getu Ambaye. (2005). Displacement-Induced Resettlement in Beles Valley Area of North Western Ethiopia. M. A. Thesis (Unpublished) Addis Ababa: Addis Ababa University.

[15] Lidahuli, Sakwa G. (2012). Social and Economic Impacts of Involuntary Resettlement During Large Scale Water Infrastructure Development: The Case of Thika Dam. Project Paper Submitted in Partial Fulfillment of The Requirement for The Award of The Degree of Master of Arts Degree in Environmental Planning and Management, University of Nairobi.

[16] Lone, Raoof A. (2014). Development induced Displacement. Journal of Social Science Research, Vol 3, No. 2.

[17] Muggah, Robert. (2003). A Tale of Two Solitudes: Comparing Conflict and Development-induced Internal Displacement and Involuntary Resettlement. Blackwell Publishing LTD, Oxford, UK.

[18] Naika, Balaji. (2016). Land Acquisition and Development Induced Displacement: India And International Legal Framework. Winter Issue, ILI Law Review. 
[19] Negi, N. Singh and Ganguly, Sujata. (2011). Development Projects vs. Internally Displaced Populations in India: A Literature Based Appraisal. Paper presented at the ESF-UniBi$\mathrm{ZiF}$ research conference on 'Environmental Change and Migration: From Vulnerabilities to Capabilities', Bad Salzuflen, Germany.

[20] Oliver-Smith, Anthony. (2001). Displacement, Resistance and The Critique of Development: From the Grass Roots to The Global. Department of Anthropology, University of Florida Gainesville, Florida.

[21] Robinson, W. Courtland. (2003). Risks and Rights: The Causes, Consequences, and Challenges of DevelopmentInduced Displacement. The Brookings Institution - Sais Project On Internal Displacement 1775 Massachusetts Avenue, Washington Dc.
[22] Tewolde Woldemariam and Fana Gebresenbet. (2014). Sociopolitical and Conflict Implications of Sugar Development in Salamago Wereda, Ethiopia. In: Mulugeta Gebrehiwot (Edi). A Delicate Balance Land Use, Minority Rights and Social Stability in the Horn of Africa. Institute for Peace and Security Studies, Addis Ababa University.

[23] Waweru, Robert. (2018). Challenges Faced in The Resettlement of Internally Displaced Persons in Kenya. ffhalshs-01807710f.

[24] World Bank. (2001). Operational Manual OP 4.12 Involuntary Resettlement. Retrieved from https://policies.worldbank.org. 